\title{
Phytochemical and Anti-Microbial Screening of Crude Extracts of Natal Fig (FicusNatalensis Kraus)
}

\section{${ }^{1}$ 'SHEYIN, F.T; ${ }^{1}$ NDUKWE, G. I; ${ }^{1}$ IYUN, O.R.A; ${ }^{2}$ ANYAM, J.V; ${ }^{1}$ HABILA J. D}

\author{
*IDepartment of Chemistry, Ahmadu Bello University, Zaria, Nigeria \\ ${ }^{2}$ Department of Chemistry, University of Agriculture, Makurdi, Nigeria \\ *Corresponding Author Email: sheyinfortune@gmail.com
}

\begin{abstract}
Traditional healers have successfully used several species of the genus Ficus to cure several ailments such as; diarrhea, dysentery, cuts, wounds, mumps, cholera, and jaundice. Ficus natalensis being of the same genus was screened for the presence of phytochemicals and antimicrobial effects. Phytochemical investigation of crude extracts of $F$. natalensis showed the presence of alkaloids, flavonoids, carbohydrates, saponins, tannins, glycosides, steroids, triterpenes and anthraquinones. The crude hexane, ethylacetate and methanol fractions had inhibitory effects on Staphylococcus aureus, Streptococcus pyrogenes, Escherichia coli, Candida krusei and Candida tropicalis. Minimum bactericidal/fungicidal concentrations (MBC)/(MFC) and Minimum inhibition concentration (MIC) were carried out on the extracts using the two fold serial dilution method at concentrations of $20 \mathrm{mg} / \mathrm{mL}, 10 \mathrm{mg} / \mathrm{mL}, 5$ $\mathrm{mg} / \mathrm{mL}, 2.5 \mathrm{mg} / \mathrm{mL}$ and $0.63 \mathrm{mg} / \mathrm{mL}$ but the crude extracts did not show inhibitory effect on Methicillin resistant Staphylococcusaureus, Shigeiladysenteriae, Vancomycin resistant enterococci, and Campylobacter jejuni.The result in this work agrees with the ethno-medicinal claim on this specie of the genus.
\end{abstract}

\section{DOI: https://dx.doi.org/10.4314/jasem.v22i9.16}

Copyright: Copyright $\odot 2018$ Sheyin et al. This is an open access article distributed under the Creative Commons Attribution License (CCL), which permits unrestricted use, distribution, and reproduction in any medium, provided the original work is properly cited.

Dates: Received: 02September 2018; Revised: 23 September 2018; Accepted: 30 September, 2018

Keywords: Ficusnatalensis (kraus); phytochemical screening, Minimum inhibitory concentration

In recent years, there has been an increase in the resistance of pathogens against antibiotics. Antibiotic resistance has become a serious issue and is further complicated by the haphazard use of modern antibiotics (Rahman et al., 2008). The discovery of effective antibiotics, vaccines and other products or methods has decreased the frightening impact of infectious diseases and has improved quality of life. However, there is a serious threat to the effectiveness of many antibiotics by the resurfacing of microbial resistance to existing chemotherapeutic agents because of their haphazard and improper use (Cowan, 1999). Also, the use of some antibiotics is linked to allergy, immune suppression, and hypersensitivity as side effects among others (Ahmad and Mehmood, 1998). The studies of bioactive components present in plants will surely do a lot or help in dealing with this issue of resistance and side effects. Sadly, many populations who live in developing countries are deprived of the advantages of modern medicine because of high cost. The financially less privileged are consequently more exposed to infectious diseases. Besides these, co-infection with multiple diseases is a serious problem to infection, prevention and treatment (Muhammed et al., 2013) hence the need for this study. Medicinal plants have been known to contain a number of effective antibacterials, antioxidants and anticancer agents which provide an alternative means of therapy to various infections caused by drug resistant bacteria, oxidative stress and dreadful diseases like cancer and other physiological disorders (Kambli et al., 2014).

Ficus natalensis is of the family Moraceae. It is generally known as the Natal fig. The plant is known for its medicinal uses by locals of Northern Nigeria as a herbal medicine for the treatment of cuts, diarrhea, dysentery, wounds, cholera and mumps. The genus Ficus (the Fig genus), has been reported to have over 800 species in 40 genera of the mulberry familyMoraceae (Kunwar and Bussmann, 2006).

Several species of ficus have been known to be of great health importance traditionally for instance, Ficus religiosa $L$. has been explored extensively in traditional medicine for the treatment of a number of ailments of the central nervous system, endocrine system, gastrointestinal tract, reproductive system, respiratory system and infectious disorders (Singh et al., 2011). F. auriculata is used in the treatment of diarrhea, dysentery, cuts, wounds, mumps, cholera and jaundice (Bhakta et al., 2011). 
Ficus species are rich in phytochemical principles such as flavanoids, glycosides, alkaloids, phenolic acids, steroids, saponins, coumarins, tannins, triterpinoids oleanolic acid, rusolic acid, $\alpha$-hydroxyursolic acid, protocatechuic acid, and maslinic acid. The nonenzymatic constituents include phenolic compounds, flavanoids, vitamin C. The enzymatic constituents of the Ficus plant are ascorbate oxidase, ascorbate peroxidase, catalase, and peroxidase. The phenolic compounds present in the genus are gallic acid and ellagic acid. Furanocoumarins have been reported in the genus (Sirisha et al., 2010). This study is aimed at screening the plant Ficus natalensis for phytochemicals and antimicrobial agents.

\section{MATERIAL AND METHODS}

Plant Collection:The plant sample of F.natalensis was collected from Area A Ahmadu Bello University Staff Quarters, Zaria. The plant was authenticated by Namadi Sanusi of the Herberium unit, Department of Biological Sciences, Ahmadu Bello University ZariaNigeria. The plant was thoroughly rinsed, air dried and pulverized into coarse powder using mortar and pestle.

Extraction: The powdered plant (550g) was introduced into a Winchester bottle (2.5L) and macerated for 48 hours with $\mathrm{n}$-hexane $(1.5 \mathrm{~L})$ then filtered and concentrated in vacuo at $40^{\circ} \mathrm{C}$. The same extraction procedure was repeated using ethyl acetate and methanol respectively. The concentrated extracts were allowed to dry in a fume hood and called the hexane, ethylacetate and methanol fractions.

Phytochemical Screening: Standard methods were employed to qualitatively analyze the fractions obtained from extraction for the presence of phytochemicals (Sofowora, 1993 and Evans 1993).

Test organisms:Staphylococcus aureus; Streptococcus pyrogenes, Escherichia coli, Candida krusei and Candida tropicalis. Methicillin resistant staphylococcus aureus, Shigeila dysenteriae, Vancomycin resistant enterococci, Campylobacter jejuni were the test organisms.

Antimicrobial Activity Test: The antimicrobial activities of the extracts of Ficus natalensiswere determined using some pathogenic microbes, from the Department of Medical Microbiology Ahmadu Bello University Teaching Hospital (ABUTH), Zaria. All microbes were screened for purity and maintained in slants of nutrient agar for bacteria and sabouround dextrose agar for fungi. Minimum Inhibitory Concentration (MIC) of the fractions against the test organisms were determined using broth dilution method and the lowest concentration of the extracts in the broth which showed no turbidity was recorded as the Minimum Inhibitory Concentration. The Minimum Bacterial Concentration/Minimum Fungicidal Concentration (MBC/MFC) was carried out to determine if the crude extracts were bactericidal or bacteriostatic. Mueller-Hinton agar was prepared and sterilized at $121^{\circ} \mathrm{C}$ for 15 minutes, transferred into Petri dishes and allowed to cool and solidify. The content of MIC in the serial dilution was sub-cultured onto the prepared medium and incubation was done at $37^{\circ} \mathrm{C}$ for $24 \mathrm{hrs}$. Thereafter each plate of the medium was observed for colony growth and was recorded as MBC/MFC (Wayne, 2016).

\section{RESULTS AND DISCUSSION}

Phytochemical Screening: The preliminary phytochemicals screening of the plant Ficus natalensis showed the presence of carbohydrates and steroids in both hexane and ethylacetate extracts. Alkaloids, saponin, triterpenes, and flavonoids were present in the ethylacetate fraction while, tannins, cardiac glycosides and anthraquinones were absent in both extracts. Also flavonoids, tannins, sapponins, and alkaloids were absent in the hexane extract. For the methanol fraction, carbohydrates, tannins, sapponins, flavonoids and cardiac glycosides were present while alkaloids, steroids, triterpenes and anthraquinones were absent (Table 1).

Table 1; Result of Phytochemical Screening

\begin{tabular}{llll}
\hline $\begin{array}{l}\text { Phytochemical } \\
\text { s Test }\end{array}$ & $\begin{array}{l}\text { Hexane } \\
\text { Fractio } \\
\text { n }\end{array}$ & $\begin{array}{l}\text { Ethylacetat } \\
\text { e Fraction }\end{array}$ & $\begin{array}{l}\text { Methano } \\
\text { I } \\
\text { Fraction }\end{array}$ \\
\hline Carbohydrate & - & + & + \\
Alkaloids & - & + & - \\
Tanins & - & - & + \\
Sapponin & - & + & + \\
Flavonoids & - & + & + \\
Steriod & - & + & - \\
Triterpens & + & + & - \\
Cardiac & - & - & + \\
Glycoside & & & \\
Anthraquinones & - & - & - \\
\hline
\end{tabular}

Key; - = Negative (absent) and $+=$ Positive

(present)

The result of antimicrobial activity of the n-hexane, ethylacetate and methanol frations showed inactivity to methicillin resistant staphylococcusaureus, Vancomycin resistant enterococci, Campylobacter jejuni and Shigella dysenteriea and active on Escherichia coli, Streptococcus pyrogene, Escherichia coli, Stelicobacter pyleri, and Candida krusei,Candida tropicalis with zones of inhibition on the microbes that showed sensitivity to the n-hexane extracts to be $21,22,20,20,18$ and $20 \mathrm{~mm}$ respectively. However, the ethylacetate extract 
showed a higher zone of inhibition than that of nhexane extract having the following values $25,26,28$, 26,25 and $26 \mathrm{~mm}$. The highest activity was recorded on Escherichia coli with zone of inhibition at 28 and the lowest at $25 \mathrm{~mm}$ on Staphylococcus aureus and Candida krusei. The methanol fraction showed zones of inhibition at 23,24, 24, 22, 23 and $22 \mathrm{~mm}$, having the highest zone of inhibition to be 24 on Staphylococcus aureus and Escherichia coli.

The Minimum Inhibitory Concentration (MIC) measured in $\mathrm{mg} / \mathrm{mL}$ for $\mathrm{n}$-hexane was observed to be $5 \mathrm{mg} / \mathrm{mL}$ against Streptococcus pyrogene,
Staphylococcus aureus, Escherichia coli, Stelicobacter pyleri, and Candida tropicalisthe highest at $10 \mathrm{mg} / \mathrm{mL}$ for Candida krusei. For ethylacetate extract, the MIC was observed for Streptococcus pyrogene, Staphylococcus aureus, Stelicobacter pyleri, Candida krusei, and Candida tropicalis to be $2.5 \mathrm{mg} / \mathrm{mL}$ and $1.25 \mathrm{mg} / \mathrm{mL}$ for Escherichia coli. The methanol extract showed MIC at $5 \mathrm{mg} / \mathrm{mL}$ for Streptococcus pyrogene, Stelicobacter pyleri, Candida krusei, and Candida tropicalis and $2.5 \mathrm{mg} / \mathrm{mL}$ for Staphylococcus aureus, and Escherichia coli.

Table 2; Antimicrobial Activity of Extracts of Ficus natalensis

\begin{tabular}{lllllll}
\hline Test Organism & HE & EA & ME & CIP & SPF & FLU \\
\hline Methicillin resistant staphylococcusaureus & $\mathrm{R}$ & $\mathrm{R}$ & $\mathrm{R}$ & $\mathrm{R}$ & $\mathrm{S}$ & $\mathrm{R}$ \\
Vancomycin resistant enterococci & $\mathrm{R}$ & $\mathrm{R}$ & $\mathrm{R}$ & $\mathrm{S}$ & $\mathrm{R}$ & $\mathrm{R}$ \\
Staphylococcus aureus & $\mathrm{S}$ & $\mathrm{S}$ & $\mathrm{S}$ & $\mathrm{S}$ & $\mathrm{S}$ & $\mathrm{R}$ \\
Streptococcus pyrogenes & $\mathrm{S}$ & $\mathrm{S}$ & $\mathrm{S}$ & $\mathrm{S}$ & $\mathrm{R}$ & $\mathrm{R}$ \\
Escherichia coli & $\mathrm{S}$ & $\mathrm{S}$ & $\mathrm{S}$ & $\mathrm{S}$ & $\mathrm{S}$ & $\mathrm{R}$ \\
Campylobacter jejuni & $\mathrm{R}$ & $\mathrm{R}$ & $\mathrm{R}$ & $\mathrm{S}$ & $\mathrm{R}$ & $\mathrm{R}$ \\
Stelicobacterpyleri & $\mathrm{S}$ & $\mathrm{S}$ & $\mathrm{S}$ & $\mathrm{R}$ & $\mathrm{S}$ & $\mathrm{R}$ \\
Shigeiladysenteriae & $\mathrm{R}$ & $\mathrm{R}$ & $\mathrm{R}$ & $\mathrm{S}$ & $\mathrm{S}$ & $\mathrm{R}$ \\
Candida krusei & $\mathrm{S}$ & $\mathrm{S}$ & $\mathrm{S}$ & $\mathrm{R}$ & $\mathrm{R}$ & $\mathrm{S}$ \\
Candida tropicalis & $\mathrm{S}$ & $\mathrm{S}$ & $\mathrm{S}$ & $\mathrm{R}$ & $\mathrm{R}$ & $\mathrm{S}$ \\
\hline
\end{tabular}

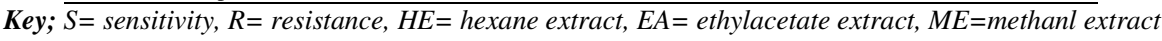

Table 3; Determination of Zone of Inhibition of the extracts on test organisms(mm)

\begin{tabular}{lllllll}
\hline Test Organism & HE & EA & ME & CIP & SPF & FLU \\
\hline Methicillin resistant staphylococcusaureus & 0 & 0 & 0 & 30 & 30 & 0 \\
Vancomycin resistant enterococci & 0 & 0 & 0 & 32 & 0 & 0 \\
Staphylococcus aureus & 21 & 25 & 23 & 30 & 32 & 0 \\
Streptococcus pyrogenes & 22 & 26 & 24 & 0 & 0 & 0 \\
Escherichia coli & 20 & 28 & 24 & 39 & 35 & 0 \\
Campylobacter jejuni & 0 & 0 & 0 & 32 & 0 & 0 \\
Stelicobacterpyleri & 20 & 26 & 22 & 0 & 30 & 0 \\
Shigeiladysenteriae & 0 & 0 & 0 & 37 & 37 & 0 \\
Candida krusei & 18 & 25 & 23 & 0 & 0 & 35 \\
Candida tropicalis & 20 & 26 & 22 & 0 & 0 & 32 \\
\hline
\end{tabular}

Key; $H E=$ hexane extract, $E A=$ ethylacetate extract, $M E=$ methanol extract, $C I P=$ ciprofloxacin, $S P F=$ spafloxacin, FLU = floconazole.

Table 4; Determination of MIC and MBC/MFC of the extract on test organisms

\begin{tabular}{lllllll}
\hline \multirow{2}{*}{ Test Organism } & \multicolumn{3}{l}{ MIC $(\mathrm{mg} / \mathrm{mL})$} & \multicolumn{3}{l}{ MBC/MFC $(\mathrm{mg} / \mathrm{mL})$} \\
\cline { 2 - 7 } & HE & EA & ME & HE & EA & ME \\
\hline Methicillin resistant staphylococcusaureus & - & - & - & - & - & - \\
Vancomycin resistant enterococci & - & - & - & - & - & - \\
Staphylococcus aureus & 5 & 2.5 & 5 & 20 & 10 & 10 \\
Streptococcus pyrogenes & 5 & 2.5 & 2.5 & 20 & 10 & 10 \\
Escherichia coli & 5 & 1.25 & 2.5 & 20 & 5 & 10 \\
Campylobacter jejuni & - & - & - & - & - & - \\
Stelicobacterpyleri & 5 & 2.5 & 5 & 20 & 10 & 20 \\
Shigeiladysenteriae & - & - & - & - & - & \\
candida krusei & 10 & 2.5 & 5 & 20 & 10 & - \\
Candida tropicalis & 5 & 2.5 & 5 & 20 & 10 & - \\
\hline
\end{tabular}

Key; $H E=$ hexane extract, $E A=$ ethylacetate extract, $M E=$ methanol extract,$-=$ Not Tested, $M I C=$ Minimum Inhibition Concentration, $M B C / M F C=$ Minimum Bacterial Concentration/Minimum Fungicidal Concentration

The Minimum Bactericidal/Fungicidal Concentrations (MBC/MFC) for n-hexane was observed to be $20 \mathrm{mg} / \mathrm{mL}$ for Streptococcus pyrogene, Staphylococcus aureus, Escherichia coli, Stelicobacterpyleri, Candida krusei, and Candida tropicalisi, ethylacetate extract showed MIC to be at
$10 \mathrm{mg} / \mathrm{mL}$ for Streptococcus pyrogene, Staphylococcus aureus, Stelicobacter pyleri, candida krusei and Candida tropicalisi, $5 \mathrm{mg} / \mathrm{mL}$ for Escherichia coli while, for methanol extract the MIC was $10 \mathrm{mg} / \mathrm{mL}$ for Streptococcus pyrogene, Staphylococcus aureus and Escherichia coli but 
$20 \mathrm{mg} / \mathrm{mL}$ for Stelicobacter pyleri. The ethyl acetate fraction was observed to be of more effect on the human pathogens used in this work compared to the other fractions.

Conclusion: Natural product has continuously been of interest due to its low cost, minimum side effects, and the level of effectiveness and for these reasons, it has always been use as a substitute for othodox medicine. The plant Ficus natalensis is rich in secondary metabolites like alkaloids, flavonoids, glycosides, terpenes, tannins, saponins and steroids. The fractions had antimicrobial activity against some selected human pathogens showing significant zones of inhibition compared to standard antibiotics. This is a window showing that bioactive principles from the plant can be used in the production of new and effective antibiotic. However, it is of great importance that further study is required for the extensive quantitative analyses of the mentioned secondary metabolites and isolation of the bioactive components in this plant.

\section{REFERENCE}

Ahmad I, Mehmood Z, Mohammad F (1998). Screening of some Indian medicinal plants for their antimicrobial properties. J Ethnopharmacol. 62:183-93.

Bhakta P. G., Ramakanta L., Chitra B. S., Amrita S., Sabita N., and Sushil P. (2011). Phytochemical Screening znd analysis of antibacterial and antioxidant activity of Ficus auriculata (Lour.) stem bark. Pharmacognosy journal; 3:21:41

Chaturvedula V. S., and Indra P. (2012). Isolation of Stigmasterol and $\beta$-Sitosterol from thedichloromethane extract of Rubussuavissimus.International Current PharmaceuticalJournal, 1(9): 239-242 http://www.icpjonline.com/documents/Vol ssue9/03.pdf

Cowan M. M. (1999). Plant products as antimicrobial agents. ClinMicrobiol Rev. 12:564-82.

Evans W. C.,Trease and Evans Pharmacognosy. 15th edn., pp. 191ñ193, 513ñ540, W.B.Saunders, Sydney/Toronto 2002.
Gairola Y, and Biswas S. (2008). Bioprospecting in Garhwal Himalayas, Uttarakhand. CurrentSci.;94:1139-44.

Kambli Y., and Patil A., Chithrashree, and Keshava R. (2014). Phytohemical screening, andEvaluation of Antibacterial, Antioxidant and Cytotoxic Activity of FicusRacemosaLinn. International Journal of Pharmacy and Pharmacuetical Sciences. 6(4) 463.

Kunwar R. M, and Bussmann R. W. (2006) Ficus (Fig) species in Nepal: a review of diversity andindigenous uses. J Eco App, (11):85-97.

Muhammed M. B, Islam R., Khatun H., Parvin S., Islam E., Islam A., and Musa A. A. (2013).Antibacterial, antidiarrhoeal, and cytotoxic activities of methanol extract and itsfractions of Caesalpiniabounducella (L.) Roxb leaves.Complementary \&AlternativeMedicine. 13:101. Available on http://www.biomedcentral.com/14726882/13/10 1

Rahman M. S., Rahman M. Z., Wahab, M. A., Chowdhury, R, and Rashid M. A. (2008). Preliminarycytotoxicity screening of some medicinal plants of Bangladesh. Dhaka Univ J Pharm Sci7:47-52.

Singh, D., Singh, B. and Goel, R. K., (2011) Traditional uses, phytochemistry and pharmacology of Ficusreligiosa: A review. Journal of Ethnopharmacology, 134(3), 565583.

Sirisha N, Sreenivasulu M, Sangeeta K, and Chetty CM.( 2010). Antioxidant properties of Ficusspecies A review. Int $J$ PharmTech Res;2(4):2174-82. $8 . \quad$ Available from:http://www.tropical.theferns.info/viewtropi cal.

Sofowora A. (1993). Medicinal Plants and Traditional Medicine in Africa. Spectrum BooksLtd., Ibadan. p. 289.

Srivastave, V.K. and. Srivastave, K.K. (1987). An introduction to chromatography. Theor. Pact. (5): 50-52.

Wayne, P. A., Clinical and Laboratory Standards Institute (2016).CLSI. Performance Standards for Antimicrobial Susceptibility Testing. 26th ed. CLSI supplement M100S. 